\section{AVALIAÇÃO IN VTTRO POR TRÊS DIFERENTES MÉTODOS DA SENSIBILIDADE DE LEVEDURAS A ANTIFÚNGICOS AZÓLICOS}

Nas últimas décadas, houve mudanças expressivas na epidemiologia das micoses humanas. Há consenso na literatura sobre o aumento na incidência das micoses sistêmicas e mudança no espectro de microorganismos causadores dessas micoses. Além disso, novas opções terapêuticas à anfotericina B foram desenvolvidas e há relatos de resistência de fungos às drogas disponíveis comercialmente. Estes fatores hoje justificam reavaliar a importância da padronização dos testes de susceptibilidade de fungos a drogas antifúngicas.

Em 1982, o National Committee for Clinical Laboratory Standards (NCCLS) estabelceu um subcomitê para discutir os testes de susceptibilidade de fungos a drogas antifúngicas, tendo em vista desenvolver um método referência ou "gold standard".

Baseado em estudos multicêntricos, em dezembro de 1992, o NCCLS divulgou uma proposta de padronização do teste de susceptibilidade de leveduras a drogas antifúngicas. O teste de referência padronizado pelo NCCLS significou um grande avanço na busca da credibilidade dos testes de avaliação in vitro das drogas antifúngicas. Entretanto, a macrodiluição é teste que exige muito espaço físico e tempo de trabalho para ser executada e não é o método econômico.

O objetivo deste trabalho foi comparar os resultados de Concentração Inibitória Mínima (CIMs) de fluconazol, itraconazol e cetoconazol frente a 100 levduras, obtidos pelo método referência, com os resultados obtidos por dois métodos alternativos: Etest e a microdiluição.

$O$ Etest (AB Biodisk, Suécia) foi realizado rigorosamente de acordo com as instruções do fabricante. A microdiluição foi realizada de acordo com os mesmos parâmetros padronizados pelo NCCLS para o método referência. As 100 leveduras foram testadas conjuntamente pelos três métodos.

Foi feita análise de correlação pareada entre as CIMs obtidas para cada droga, referente aos 100 organismos testados, contrastando-se valores gerados pelo método referência com aqueles obtidos com os 2 métodos alternativos. De acordo com o critério adotado, as CIMs obtidas pelo método alternativo foram consideradas equivalentes ao método-referência quando ambas apresentaram exatamente o mesmo valor

Recebido para publicação em 22/11/94.

\section{IN VITRO EVALUATION OFYEASTS SUSCEPTIBIIITY TO ANTIFUNGAL AZOLES, BY USING THREE DIFFERENT TESTING METHODS}

Paralleling the increased prevalence of fungal infections has been the introduction of new antifungal agents and the recognition of resistant isolates to antifungal drugs. Consequently, there is a greater need for a precise in vitro susceptibility testing method as a guide to selecting and monitoring antifungal therapy.

Despite advances represented by the recent standardization of a macrobroth procedure by the National Committee for Clinical Laboratory Standards (NCCLS), additional efforts are necessary for development of simpler and more economical methods.

The main purpose of this study is to compare the Minimal Inhibitory Concentration (MIC) results of fluconazole, ketoconazole and itraconazole obtained by the reference macrobroth procedure with 2 alternative methods, Etest and microdilution, against 100 yeasts representing 5 different species of relevant human pathogenic fungi.

The Etest was performed according to manufacturer's instructions. The reference macrobroth dilution method and the microdilution procedure were both performed according to the proposed NCCLS standard.

The MIC results obtained by the macrobroth procedure was compared "head to head" to each one of both alternative methods: Etest and microdilution. Essential agreement was considered when reference results and results obtained by an alternative method agreed exactly or were within 1 twofold dilution.

Etest and microdilution were less labor intensive than the macrobroth dilution and both alternative methods can be performed by any routine laboratory.

The endpoint readings for the azoles, by all 3 methods, presented problems in the reading 
Resumo de Tese. Colombo AL. Avaliação in vitro por três diferentes métodos da sensibilidade de leveduras a antifüngicos azólicos. Revista da Sociedade Brasileira de Medicina Tropical 28:289-290, jul-set, 1995.

ou diferença de apenas 1 diluição (valor referência \pm 1 diluição).

A execução do método referência foi muito mais laboriosa que ambos os métodos alternativos estudados. Os três métodos apresentaram dificuldades na leitura de seus resultados devido à presença do "trailing". Os resultados de Etest e macrodiluição tiveram indices de concordância que variaram significativamente entre as combinaçôes de droga $\mathrm{e}$ espécies de levedura analisadas. De modo geral, estes índices variaram de 30\% a 100\% dos resultados, sendo que os piores índices foram obtidos com amostras de C. tropicalis. Entre os resultados discordantes obtidos por Etest $\mathrm{e}$ macrodiluição, as CIMs referentes ao Etest foram menores que os valores referência.

Os índices de concordância entre CIMs obtidas por microdiluição e método-referência tiveram comportamento mais homogêneo entre as espécies de leveduras testadas. Das 15 diferentes combinações entre as 3 drogas e 5 espécies avaliadas, 12 apresentaram índices de concordância entre $80 \%$ e $100 \%$ dos resultados. Entre os resultados discordantes obtidos pelos dois métodos, as CIMs referentes à microdiluição foram maiores que os valores referência.

Avanços significativos foram alcançados na padronização de testes de sensibilidade de fungos a drogas antifúngicas. Entretanto, é fundamental a realização de estudos sobre a correlação in vitro $\mathrm{x}$ in vivo de seus resultados, para permitir a análise e interpretação da significância clínica dos dados obtidos nestes testes. interpretation. The trailing phenomena seen in the macrobroth dilution was also present in the Etest, being manifested by the growth of microcolonies inside the inhibition zone.

The range of essential agreement rates between Etest and reference method was from $33 \%$ to $100 \%$, according to the species and drugs tested. C. tropicalis isolates produced the lowest essential agreement rate between the two methods. Among the desagreement results between both methods, Etest generated lower MIC results than the reference method.

The range of essential agreement rates between microdilution and reference method was from $64 \%$ to $100 \%$, according to the species and drugs tested. In addition, the essential agreement rates in 13 of the 15 organism-drug combinations tested by both methods, were $\geq$ $80 \%$. Among the desagreement results between both methods microdilution generated higher MIC results than the reference method.

Finally, despite advances represented by the standardization of antifungal susceptibility testing, additional efforts are necessary to study

\section{Arnaldo Lopes Colombo}

Tese apresentada à Escola Paulista de Medicina para obtenção do Título de Doutor.

São Paulo, SP, Brasil, 1994 